\title{
Warm Compress Of Pain Level In Patients Elderly Who Suffers Rematic
}

\author{
Firdaningsih', Amirullah', A.Nurlaela Amin ${ }^{3}$ \\ S1 Nursing Study Program, Stikes Panrita Husada Bulukumba, Indonesia ${ }^{1}$ \\ Departemen Surgical Medical Nursing , Stikes Panrita Husada Bulukumba, Indonesia ${ }^{2}$ \\ Departemen Surgical Medical Nursing, Stikes Panrita Husada Bulukumba ,Indonesia 3 \\ Corresponding Autor : Firdaningsihfirda@gmail.com
}

\begin{abstract}
The background based on data found at the society health center of Bontonyeleng, district of Gantarang, the regency of Bulukumba.it received 45 rheumatic patients in 2017. The aim of this research is to find out the influence of warm compress to decrease the pain degree of rheumatic patients qat society health center of Bontonyeleng, district of Gantarang, the regency of Bulukumba. The method has taken in this research was experimental research ( pre-experimental design) using the one-group pretest-posttest design. The population sample in this research was 30 respondent, it was taken using shack formula. Data analyse result using T-test match with value $\mathrm{p} 0,000$. the research result gained before applying warm compress ton lo pain degree patients are 2 respondents or (6.7\%) medium paint degree patient is 28 respondents or $(93,3)$. While the result after applying a warm compress for low pain degree patients is 20 respondents or (66.7\%) medium pain degree patient is 10 respondents or (33.3\%). Based on explanations above, we can conclude that there is the influence of warm compress to decrease pain degree for the rheumatic patient especially for old society at society heald center of Bontonyeleng, district of Gantarang, the regency of Bulukumba so that is why people in bukit harapan village, district of Gantarang, regency of Bulukumba suggests for those who feel the pain that indicates rheumatic should not ignore and do an action like applying warm compress immediately using correct tools to decrease the pain or doing health check as soon as possible to nearby medical care.
\end{abstract}

\section{Keywords: Warm Compress, Reumatic Pain}

\section{INTRODUCTION}

Rheumatism is a disease that has long been known and is widespread throughout the world which symmetrically experiences inflammation so that swelling, pain and eventually cause damage to the inside of the joints and will interfere with the activity/work of patients. Rheumatism is more common in people who have excess activities in using the knee such as peddlers, and workers who squat a lot because there is excessive emphasis on the knee, generally the more strenuous activities carried out by someone in daily activities, the more frequent patients will experience rheumatism especially in the joints and more often in the morning (Bawarodi, 2017).

According to data from the World Health Organization (WHO), it is reported that $20 \%$ of the world's population has rheumatoid arthritis. Where $5-10 \%$ are those aged 5-20 years and 20\% of those who are 55 years old (Wiyono, 2010). More than 355 
million people worldwide suffer from rheumatic diseases. That means, every six people in the world, one of whom is a Rheumatoid sufferer, with a total population of around 7 billion people in 2012. It is estimated that this number continues to increase until 2025 with an indication of more than 25\% will experience paralysis (Andriani, 2016).

Pain is the most common reason people seek health care. Individuals who feel pain Feeling depressed or suffering and looking for efforts to eliminate pain. Pain is subjective, no two individuals experience the same pain and no two occurrences of the same pain produce an identical response or feeling in an individual. Pain is a source of frustration, both for clients and health workers. The International Association for Pain Research (International Association for the Study of Pain, IASP) defines pain as "a subjective sensory and unpleasant emotional experience associated with tissue damage (Pinandita, 2012).

Warm compress is one of the pain management by giving heat energy through conduction, where the heat can cause vasodilation (dilation of blood vessels) increase muscle relaxation thereby increasing circulation and increasing intake, oxygen, and nutrients to the tissues. Warm water compress is more effective than compresses alcohol (Setyawan, 2014).

Based on data obtained at the Bontonyeleng Community Health Center, Gantarang District, Bulukumba District, the number of rheumatic patients in 2017 was 45. Based on the phenomenon mentioned above, researchers are interested in examining the "Effect of Warm Compresses on Pain Levels in Elderly Patients Suffering from Rheumatism. Purpose To find out the effect of warm compresses on the level of pain in elderly patients suffering from rheumatism in the Bontonyeleng Community Health Center, Gantarang District, Bulukumba Regency.

\section{MATERIALS AND METODS}

The research design used in this study was an experimental research design (preexperimental design) using one-group pretest-posttest design. Experimental research is a study conducted by conducting trials / interventions or manipulations on research subjects then the effects of these interventions are measured and analyzed (Sugiyono, 2014). Population is a unit where a research result will be applied (generalized). Ideally, research is carried out on population, because it can see a picture of the entire population as a unit where the results of the study will be applied (Dharma, 2013). 


\section{COMPRAHENSWE HiBHLT GRBE}

The population in this study were all rheumatic patients in 2017 patients in the Bontonyeleng Community Health Center, Gantarang District, Bulukumba District. Sampling using sampling technique is a sampling technique to determine the sample to be used in research, in this study the sampling technique used by researchers is probability sampling with using simple random sampling. (Sugiyono, 2014). Instrumen penelitian adalah suatu alat yang digunakan oleh peneliti untuk mengobservasi, mengukur atau menilai suatu fenomena (Dharma, 2013). In this study the authors used an observation sheet to determine the effect of warm compresses on pain in elderly patients suffering from rheumatism. The instrument used in this study is the observation sheet on the dependent and independent variables. Research instruments used to measure pain scales, using observation sheets before and after warm compresses.

Data analysis was performed to answer the research hypothesis, for this reason statistical tests were used that matched the research variables. Data were analyzed by: (1). Univariate Analysis, Analysis is done to see the proportion. (2). Bivariate Analysis, Bivariate test is carried out to look for the influence between the independent variable and the dependent variable with the test used is the Paired T Test.

\section{RESULT}

Table 1. Distribution of Characteristics of Respondents

\begin{tabular}{lcc}
\hline Gender & n & Persentage (\%) \\
\hline Male & 11 & 36.7 \\
Female & 19 & 63.3 \\
\hline Age & & \\
\hline Late Adulthood & 1 & 3.3 \\
Early Elderly & 14 & 46.7 \\
Late Elderly & 8 & 26.7 \\
Old Man & 7 & 23.3 \\
\hline Level Of Eduacation & & \\
\hline Not School & 3 & 10.0 \\
SD & 20 & 66.7 \\
SMP & 7 & 23.3 \\
\hline Profession & & \\
\hline Farmers & 9 & 30.0 \\
Housewife & 17 & 56.7 \\
Entrepreneur & 1 & 3.3 \\
Trader & 3 & 10.0 \\
\hline Amount & 30 & 100.0 \\
\hline
\end{tabular}




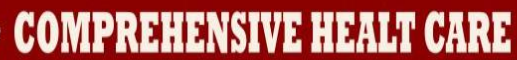

Based on (Table 1), the frequency distribution of male sex is 11 respondents or around (36.7\%), and female sex is 19 respondents or around (63.3\%), based on the age distribution criteria of late adult age of 1 person or around (63.3\%), aged 14 or around (46.7), elderly or 8 (26.7\%), and 7 or 23 (23.3\%) in the elderly, based on the distribution of educational creativeness who never attended school by 3 respondents or around (10.0\%), and those with an elementary school education of 20 respondents or around (66.7\%), distribution with an education of junior high school as much as 7 respondents or around (23.3\%), based on the distribution of job criteria working as farmers as many as 9 respondents or approximately (30.0\% ) and respondents work as IRT as many as 17 respondents or approximately (56.7\%) and respondents who work as entrepreneurs as many as 1 or about (3.3\%). Based on the distribution of traders as many as 3 respondents or about (10.0\%).

Table 2. Distribution of Number of Respondents Based on Pain Levels in Rheumatic Patients

\begin{tabular}{lcccc}
\hline Pain Category & \multicolumn{2}{c}{ Pra Intervention } & \multicolumn{2}{c}{ Post intervention } \\
\hline & $\mathrm{n}$ & $\%$ & $\mathrm{n}$ & $\%$ \\
\hline Mild & 2 & 6.7 & 20 & 66.7 \\
Moderate & 28 & 93.3 & 10 & 33.3 \\
\hline Amount & $\mathbf{3 0}$ & $\mathbf{1 0 0}$ & $\mathbf{3 0}$ & $\mathbf{1 0 0}$ \\
\hline
\end{tabular}

Based on (Table 2) The results of the study that were obtained before the warm water compresses were performed which experienced mild pain of 2 respondents (6.7\%) and moderate pain as many as 28 respondents or approximately (93.3\%). Whereas after a warm water compress was obtained the level of mild pain was 20 respondents or around (66.7\%) and moderate were 10 respondents or around (33.3\%). Tabel 3. Pengaruh Kompres Hangat Terhadapa Tingkat Nyeri Pada Pasien Rematik

\begin{tabular}{lcccc}
\hline \multicolumn{1}{c}{ Intervention } & $\mathbf{N}$ & $\begin{array}{c}\text { Median } \\
\text { (Minimum-Maksimum) }\end{array}$ & Average & $P$ \\
\hline Pain before warm compresses & 30 & 1.93 & .254 & 0,000 \\
\hline Pain after warm compresses & 30 & 1.33 & .479 & \\
\hline
\end{tabular}

Based on (Table 3) The results of the analysis using paired $\mathrm{T}$ test obtained significance value of P 0,000, it can be concluded that "There is an Influence of Warm 


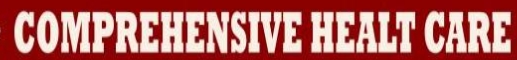

Compress Against Pain Level in the Bontonyeleng Public Health Center Working Area, Gantarang District, Bulukumba Regency.

\section{DISCUSSION}

Effect of warm compresses on pain levels in elderly patients suffering from rheumatism in the work area of the Bontonyeleng Health Center in Gantarang District, Bulukumba Regency. Based on the results of the analysis using the paired $\mathrm{T}$ test, $\mathrm{a}$ significance value of $\mathrm{P} 0,000$ was obtained, so it can be concluded that "There is an Influence of Warm Compress Against Pain Level in Elderly Patients Affected by Rheumatism in the Work Area of Bontonyeleng Public Health Center, Gantarang District, Bulukumba Regency.

The results of the study were obtained before the warm water compress is done on average respondents felt moderate pain. The results of the study that were obtained after warm water compresses were done on average respondents experienced changes in pain, because before the compress was done, respondents felt moderate pain and after the compress was done most respondents felt mild pain. There was an Effect of Warm Compress On Pain Levels in Elderly Patients Suffering from Rheumatism In the work area of the Bontonyeleng Community Health Center, Gantarang District, Bulukumba Regency.

\section{CONCLUSION}

The researchers suggest that the results of this study can be used as material to increase insight in the field of research as well as increase knowledge about the effect of warm compresses on pain levels in elderly patients suffering from rheumatism in the Bontonyeleng Community Health Center, Gantarang District, Bulukumba Regency in 2018. As for suggestions As a reference data for Bontonyeleng Public Health Center, Gantarang District, Bulukumba Regency in 2018 To provide guidance or counseling to people suffering from rheumatic diseases. For nursing research, it is hoped that further research can be carried out on the Effect of Warm Compresses on Pain Levels in Elderly Patients Ysmng Suffering from Rheumatism in the Bontonyeleng Public Health Center area of Bulukumba District year 2018. Suggestions for sufferers of rheumatic diseases are advised to the community so that when they feel complaints that may be indicated by rheumatism so as not to underestimate it and immediately take actions such as warm compresses by using tools that can reduce pain, or immediately check himself closest health care. 


\section{REFERENCES}

Aklima, N. (2017). Pengetahuan dan Sikap Manula tentang Penyakit Rematik di Kemukiman Lamlhom Kecamatan Lhoknga Kabupaten Aceh Besar. IImiah Mahasiswa Fakultas Keguruan dan Ilmu Pendidikan Unsyiah .

Andriani, M. (2016). Pengaruh kompres hangat terhadap penurunan intensitas nyeri artritis rheumatoid pada lanjut usia. Ipteks terapan .

Aprina. (2017). Relaksasi progresif terhadap intensitas nyeri post operasi ,BPH (benigna prostat hiperplasia). Kesehatan .

Bawarodi, f. (2017). Faktor-faktor yang berhubungan dengan kekambuhan penyakit rematik di wilayah puskesmas beo kabupaten talaud. keperawatan .

Charlish, A. (2010). Artritis dan Reumatik. Citra Aji Parama.

Dahlan, A. (2017). Pengaruh terapi kompres hangat terhadap nyeri haid (Dismenorea) pada siswi smk perbankan simpang haru padang . Journal Endurance.

Dharma, K. K. (2013). Metode Penelitian Keperawatan. cv. Trans info Media.

Fitrianingrum. (2013). Pengaruh teknik relaksasi Efflurage Terhadap Penurunan Nyeri Pada Pasien Post Appendictomy di Rumah Sakit Umum Daerah Kabupaten Kudus. Kesehatan Keperawatan .

Mubarak, S. N. (2008). Buku Ajar Kebutuhan Dasar Manusia teori dan aplikasi dalam praktik. jakarta : EGC, 2007.

Noorhidayah. (2013). Terapi kompres panas terhadap penurunan tingkat nyeri klien lansia dengan nyeri rematik.

Pinandita, L. (2012). pengaruh Teknik Relaksasi pengaruh genggam jari terhadappenurunan intensitas nyeri pada pasien post operasi laparotomi. ilmia kesehatan keperawatan .

Rantiyana. (2017). Pengaruh Terapil Murottal AL Qur,an Terhadap Nyeri Pada Pasien Luka Bakar. Kebidanan dan Keperawatan .

Rasubala, g. f. (2017). pengaruh teknik relaksasi benson terhadap skala nyeri pada pasien post operasi di rsup prop .dr.r.d kandou dan rs tk.III.r.w. mongisidi teling manado. keperawatan

Renovaldi, D. (2014). Perbandingan Validitas alat ukur Nyeri I Antara Self-Report Pain Scale dan Observational pain Scale Pada nyeri Akut Anak usia 3-7 tahun.

Mellynda. (2014). Pengaruh Kompres Hangat Terhadap Penurunan Skala Nyeri Pada Penderita Gout Arthritis Di Wilayah Kerja Puskesmas Bahu Manado tahun

Saryono, S. A. (2010). Metodologi Penelitian Kebidanan. Ruha medika.

Setyawan, D. (2014). Pengaruh pemberian kompres hangat pada leher terhadap penurunan intensitas nyeri pada pasienhipertensinsi di rsud tugurejo semarang. Jurnal IImu Keperawatan dan Kebidanan . 
Sodikin. (2011). Asuhan keperawatan anak gangguan sistem gastrointestinal dan hepatobilier. Jakarta: salemba medika.

Sugiyono, D. p. (2014). Metode penelitian.

Tamsuri, A. (2007). Konsep dan penatalaksanaan nyeri. Jakarta: EGC.

Yulianti. (2012). Gambaran pengetahuan keluarga tentang pengobatan rematik dengan air rebusan jahe dikelurahan meranti pandik wilayah kerja puskesmas rumbai

Yusrizal. (2012). Pengaruh Teknik Relaksasi Nafas Dalam dan Masase Terhadap Penurunan Skala Nyeri Pasien Pasca Apendiktomi di Ruang Bedah RSUD Dr. M. Zein Painan. Keperawatan. 